\title{
DETECTION LAND COVER CHANGES OF THE BAQUBA CITY FOR THE PERIOD 2014-2019 USING SPECTRAL INDICES
}
A.B. Khalaf
Lecturer
Dep. Soil and Water Resources.
A. I. J. Al-Jibouri
Lecturer
Dep. Desrtficition.

Coll. of Agriculture. University of Diyala. Coll. of Agriculture. University of Baghdad

Dr.ahmedbahjat@agriculture.uodiyala.edu.iq_Afakibrahem1963@gmail.com

\section{ABSTRACT}

This study was conducted on the Land coverings of the city of Baquba and its outskirts in Diyala province, central Iraq, between latitudes $44^{\circ} 42^{\prime} 31.78^{\prime \prime}-44^{\circ} 33^{\prime} 14.99^{\prime \prime}$ and $33^{\circ} 41^{\prime}$ $46.66^{\prime \prime}-33^{\circ} 48^{\prime} 23.18^{\prime \prime}$ an area of $180,835 \mathrm{~km}^{2}$. In order to classify the earth covers, it was relied on the field survey to determine the grounding points. Also used two satellite data from Landsat 8, the first one on 23/3/2014, the second on 21/3/2019, and the production of Normalized Difference Vegetation Index (NDVI), Normalized Difference Water Index (NDWI) and Normalized Differences Built- up the Index (NDBI) maps. The results of the survey was showed five varieties are vegetation cover, agricultural land, water, buildings and barren land. They were identified and compared with the 75 land control points, The accuracy of the classification was calculated using Kappa It was 89\%, and purely concluded that the use of manuals NDVI, NDWI and NDBI was useful for classifying Land coverings and detecting changes as they are considered an easy and fast method.

Key words: vegetation index, NDVI, NDWI, NDBI. remote sensing

خلف والجبوري

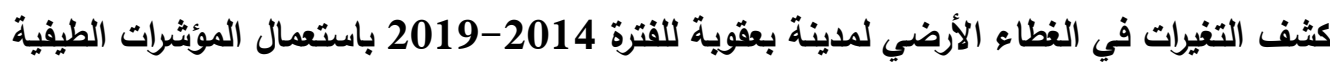

اقفاق ابراهيم جمعة الجبوري

مدرس

قسم التصحر .كلية علوم الهندسة الزراعية.جامعة بغداد

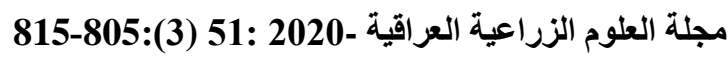

احمد بهجت خلف

مدرس

قسم التربة والموارد المائية.كلية الزراعة.جامعة ديالى ملى

المستخلص

أجريت هذه الدراسة على الأغطية الأرضية لمدينة بعقوية واطرافها في محافظة ديالى وسط العرلق والواقعة بين خطي طول " مقاره 180,835 كم2. ولغرض تصنيف الأغطية الارضية ، تم الاعتماد على المسح الحقلي لتحديد نقاط ضبط ارضية ، وكذلك باستعمال بيانين فضائين للقمر الصناعي Landsat 8 الاولى ملتقطة بتاريخ 2014/3/23 والثانية ملتقطة بتاريخ 2019/3/21 ومن خلال انتاج خرائط دليل الاختلاف الخضري الطبيعي(NDVI)، دليل اختلاف الماء الطبيعي (NDWI) و دليل اختلاف المباني الطبيعي (NDBI) وتصنيفه من البيان الفضائي ومقارنته مع خارطة التصنيف الموجه للبيان الفضائي ولفترتي الدراسة ،اظهرت نتيجة التصنيف الحصول على خمسة أصناف هي غطاء نباتي،أراضي زراعية ، مياه، أبنية وأراضي جرداء.وتم التعرف عليها ومقارنتها مع نقاط الضبط الارضي والبالغ عددها 75 نقطة، حسبت دقة التصنيف باستعمال المقياس

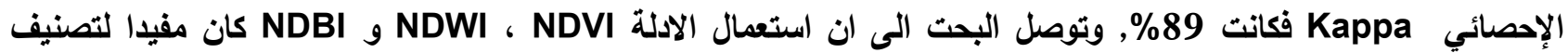

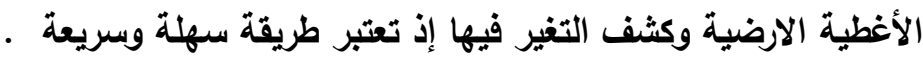
كلمات المفتاحية :دليل الغطاء النباتي، NDVI، NDWI، NDBI، التحس النائي . 


\section{INTRODUCTION}

The use of remote sensing techniques in the classification and detection of change in Earthbased, coatings on electromagnetic radiation through satellite images is very effective for obtaining a better understanding of the Earth's environment $(18,26)$. Remote sensing data is one of the most important sources of available ground information, allow systematic and costeffective monitoring, and monitoring of the Earth and its resources, comparisons among different time periods and the production of maps. $(1,12)$. Changes in natural resources as shown in land cover and land-use change (LCLUC) are one of the most important components of global environmental change $(20,27)$. Rapid growth in population and industrialization has led to increased exploitation of natural resources to meet the basic human societal needs (17), which requires continued monitoring and development of their management and investment programs through remote sensing sensors and geographic information systems. (21). Spectral indics were obtained from satellite images is a very simple and effective algorithm for quantitative and qualitative assessment of earth cover (6). In a study of the researcher Daniela et al. (4) using spectral indics, especially the NDVI (Normalized Difference Vegetation Index) and the NDWI(Normalized Difference Water Index) in detecting change in the earth cover in Donana, Spain for the years 2009-2010. The study found that the use of spectral indics was good Detection of change of ground cover for the study area. Kusay and Muntaha (8) found that the best indics for land degradation was the indics of modified soil cover (MSAVI) as well as (NDVI), which showed the largest percentage change at area (Husseini) irrigation project at Karbala governorate between 1989 and 2011. The researcher Manikandan (11) Use the Water Ratio Index (WRI), (NDWI) and Modified Normalized Difference Water Index (MNDWI), along supervised classification. The study was showed that the lakes of Chelekleka in India had a decrease of $1.309 \mathrm{~km} 2$ by $79 \%$ between $2000-2017$ and NDWI was the best guide for quantitative expression Change. Either Taghreed (24) has used indics Difference Vegetation-Index (DVI), Perpendicular Vegetation Index (PVI) and Weighted Difference Vegetation Index (WDI) for detection and control of vegetation cover between 2001-2002 at Al Fit'ha north of Salah al-Din Governorate. The researcher found that the indics is better than the other indics used in the study. The objective of this study was to adopt the modern scientific methods based on the required software in the preparation of the required information to classify the Land coverings and detect the change in these covers at the city of Baquba in a sophisticated scientific method by creating land classification maps and showing the various practical applications of remote sensing and geographic information systems.

\section{MATERIALS AND METHODS}

\section{Study area}

The study area was determined by field visits using the Global Positioning System (GPS).. In addition to using Google Earth, The administrative boundaries of Diyala Governorate are limited to $44^{\circ} 42^{\prime} 31.78^{\prime \prime}$ $44^{\circ} 33^{\prime} 14.99^{\prime \prime}$ and $33^{\circ} 41^{\prime} 46.66^{\prime \prime}-33^{\circ} 48^{\prime}$ $23.18^{\prime \prime}$ an area of $180,835 \mathrm{~km}^{2}$.

\section{Satellite image}

In this study, two satellite images were used for the satellite Landsat 8, the OLI_TIRS sensor (Path 168 and Row 37), the first was taken on 23/3/2014 and the second was taken on $21 / 3 / 2019$ as in Figure 1. 


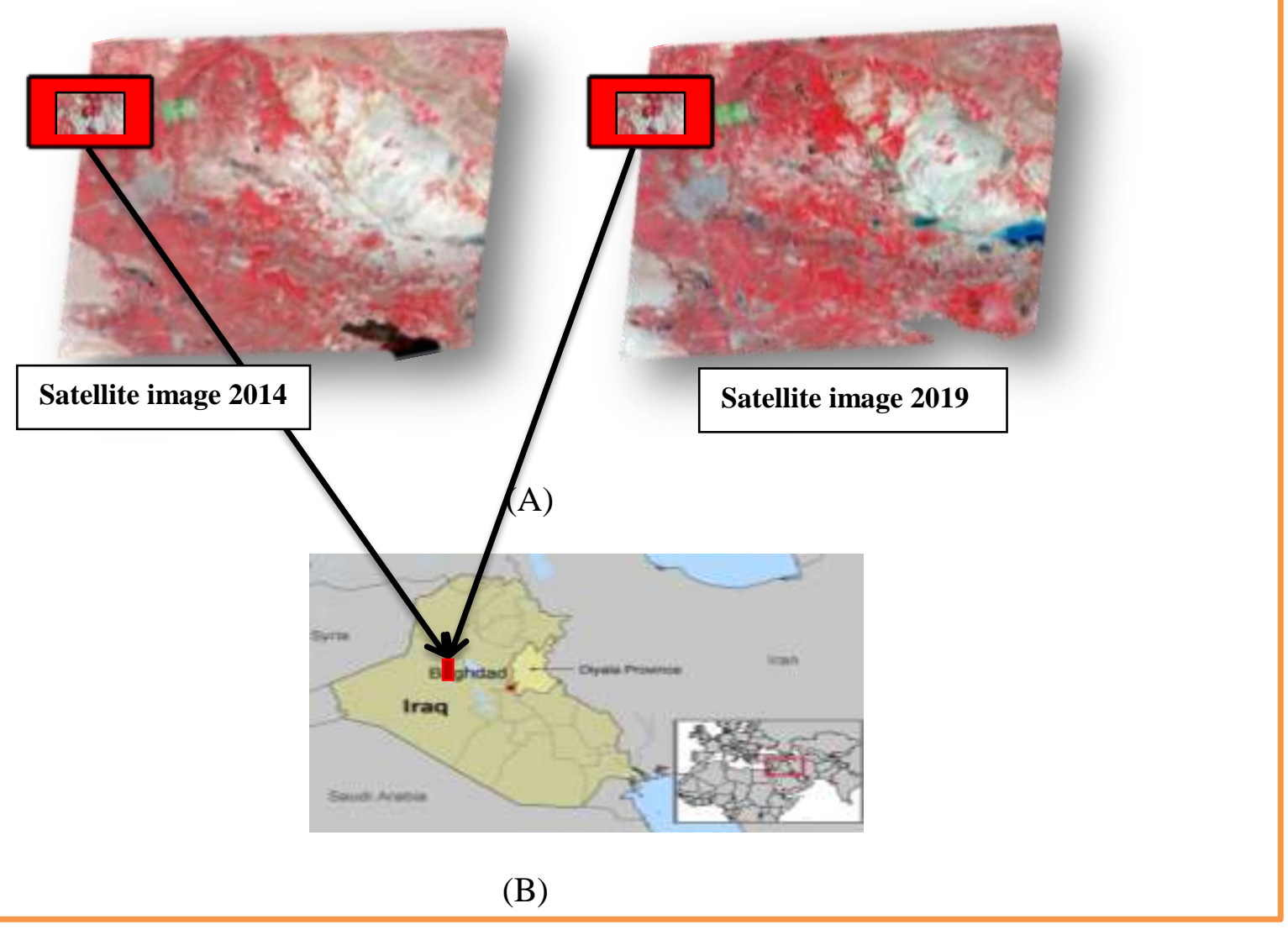

Figure 1. The area of study in Baquba is part of the satellite's Landsa(2014), Landsat 8 (2019)(A) and Diyala province (B).

\section{Processing of satellite images}

In order to obtain a spatial resolution of $15 \mathrm{~m}$, Landsat 8 was integrated or collected by using the Erdas Imagine V. 14 program. After that, the study area was cut. Using ArcMap 10.3.1, as in Figure 2.

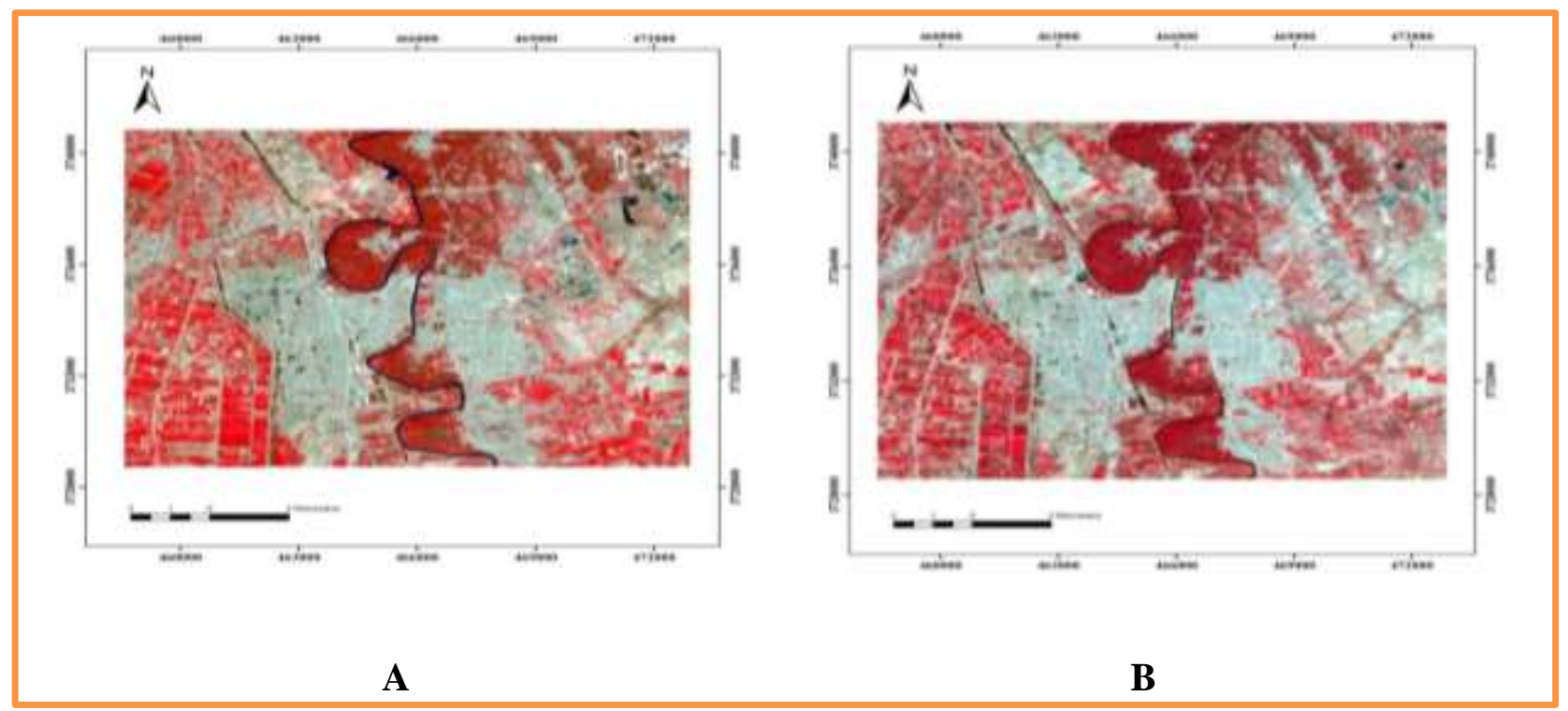

Figure 2. The studied area in Baquba is part of the satellite A (Landsat 8 2014) and B (Landsat 8 2019).

Spectral indics used in the study

Normalized Difference Vegetation Index (NDVI): It is one of the most well-known spectral and plant indics used in the study of vegetation. It has been used extensively in the study of temporal and spatial dynamics of vegetation cover (14). The NDVI index is based on the spectral characteristics of 
vegetation, compared to vegetation-free areas. The red colo absorbs heavily and reflects the nearby infrared radiation. This occurs by the chlorophyll found in the green leaves. Therefore, areas with dense vegetation cover their spectral properties in the infrared and infrared ranges, Areas with less dense or plantfree vegetation (7). The NDVI index is calculated based on the difference in the amount of reflected radiation in the nearby red and infrared channels divided by the sum of the reflection in the two channels. The value of the NDVI index is between $(-1$ and +1$)$, the value of which is close to $1(0.8-0.3)$ when there is dense vegetation, about 0.1 in the case of bare soil, and $(0.2-0.3)$ with shrubs and grasses. The negative values of the guide are recorded in the case of clouds and snowcapped areas $(5,16)$. Its equivalent $(22)$ :

$N D V I=(\mathbf{N I R})-$ Band $($ Red $)$

Band $($ NIR $)+$ Band $($ Red $) \ldots \ldots .1$

As:

NIR $=$ Near Infrared rays .

$\mathrm{RED}=$ red rays

Using Erdas Imagine V.14 and ArcMap 10.3.1, the NDVI map of the study area and for the 2014 and 2019 periods, as shown in Figure 3.

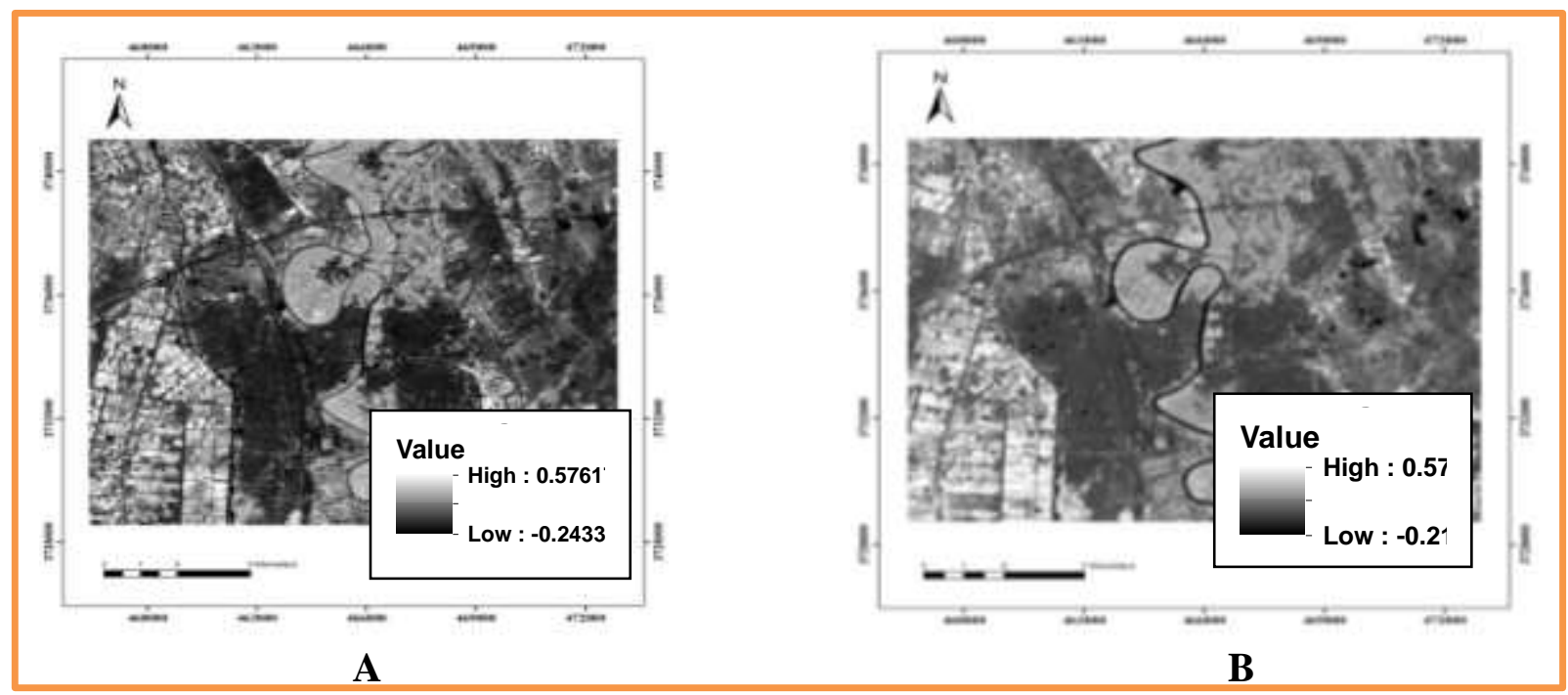

Figure 3. NDVI map of the study area and for the two periods 2014 (A) and 2019 (B)

Using Erdas Imagine 2014 and ArcMap 10.3.1. Based on the NDVI map, we conducted the classification process and (buildings, residential buildings and roads), obtained 5 main categories: buildings water, barren land, vegetation cover, and agricultural land, as shown in Figure 4.

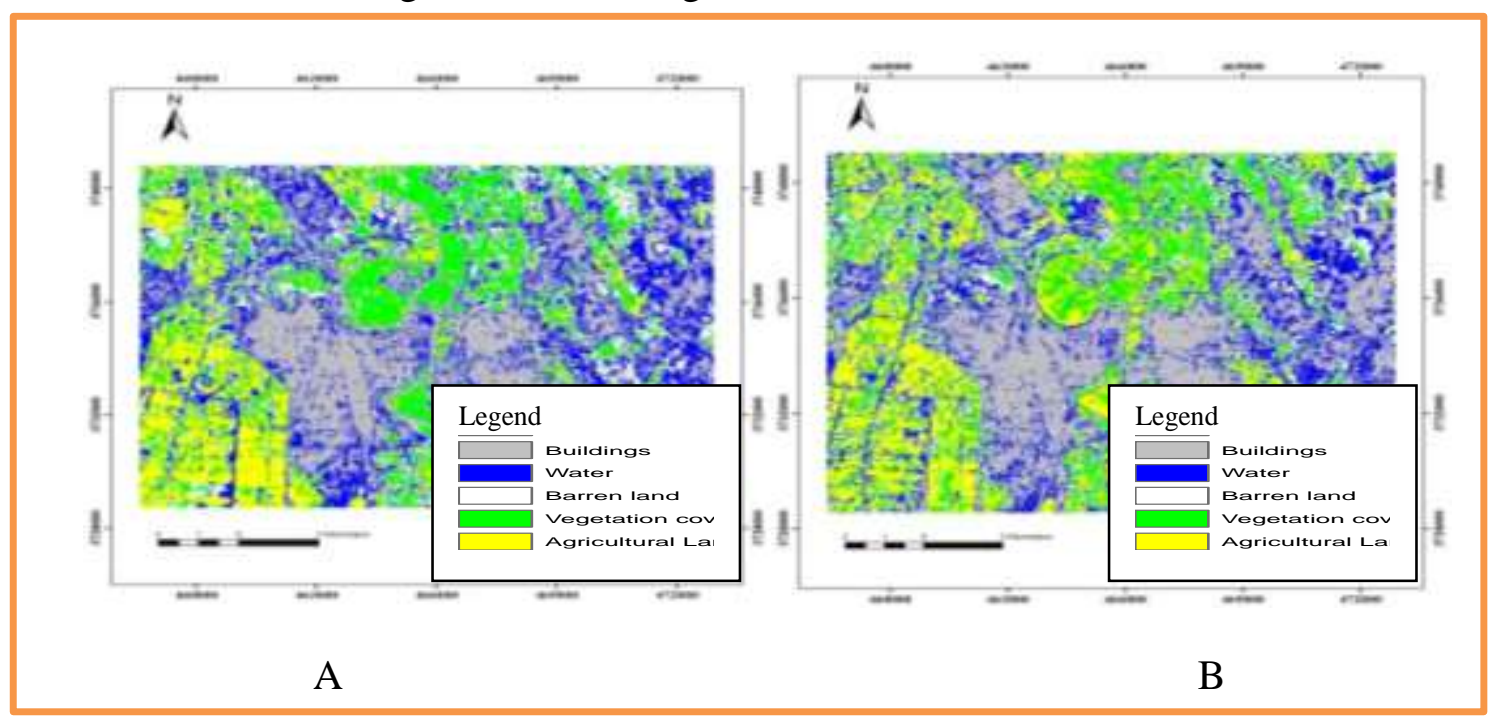

Figure 4. NDVI map of the study area and for the two periods 2014 (A) and 2019 (B) 


\section{Normalized Differences Water Index}

The NDWI was determined using the same NDVI principle as the spectral reflectivity of the water is high in the range of the green wave length (0.52-0.60) $\mu \mathrm{m}$ and very little in the near infrared wavelength (0.76-0.90) $\mu \mathrm{m}$. The high reflectivity of the plant and the soil. The range of red wavelengths makes the NDWI values positive for the aquatic regions, so the regions appear to be bright and have positive values in NDWI when the green and built areas are dark and dark and have negative or zero values $(2,3)$. Equivalent (25):

$\mathrm{NDWI}=\quad($ GREEN $)-\boldsymbol{B a n d}(\mathrm{NIR})$

Band(GREEN)+Band (NIR) .....2

Using the Erdas Imagine V.14 program and the ArcMap 10.3.1 program, the NDWI map of the study area and for the 2014 and 2019 periods was prepared as in Figure 5

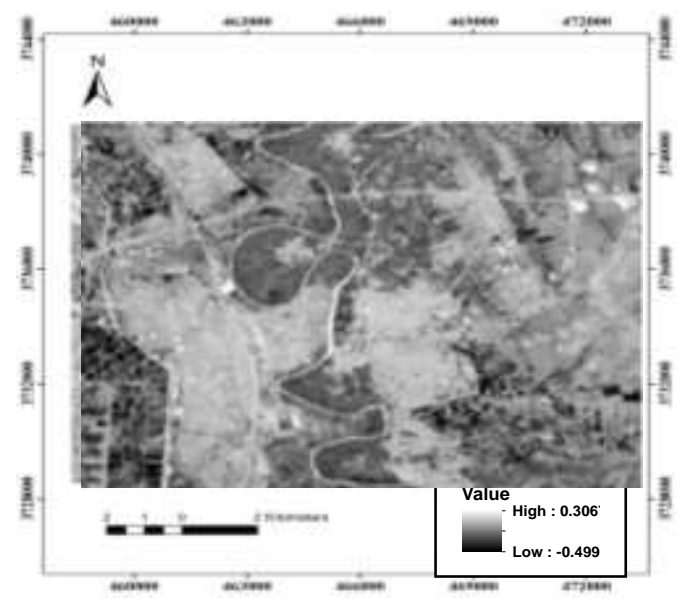

A

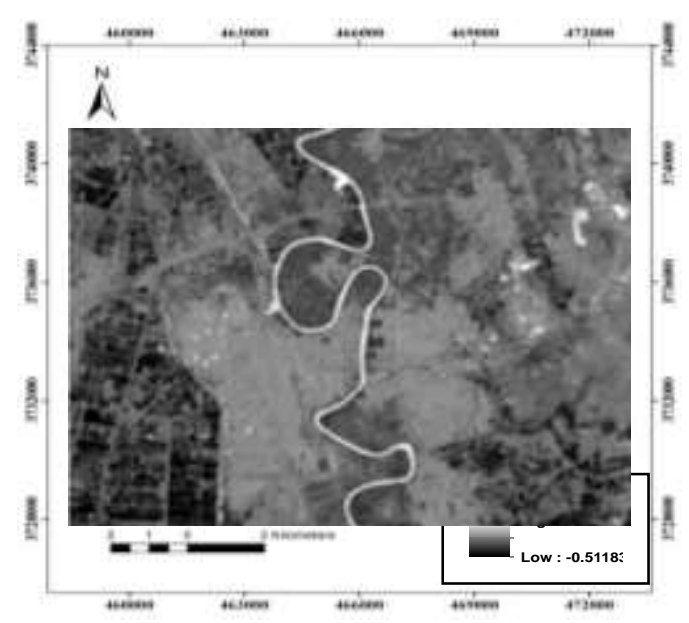

B

Figure 5. NDWI map of the study area and for the two periods 2014 (A) and 2019 (B).

Using Erdas Imagine 2014 and ArcMap 10.3.1. Based on the NDWI map, we conducted the classification process and obtained 5 main categories: buildings (buildings, residential buildings and roads), water, barren land, vegetation cover, and agricultural land, as reveal in Figure 6.

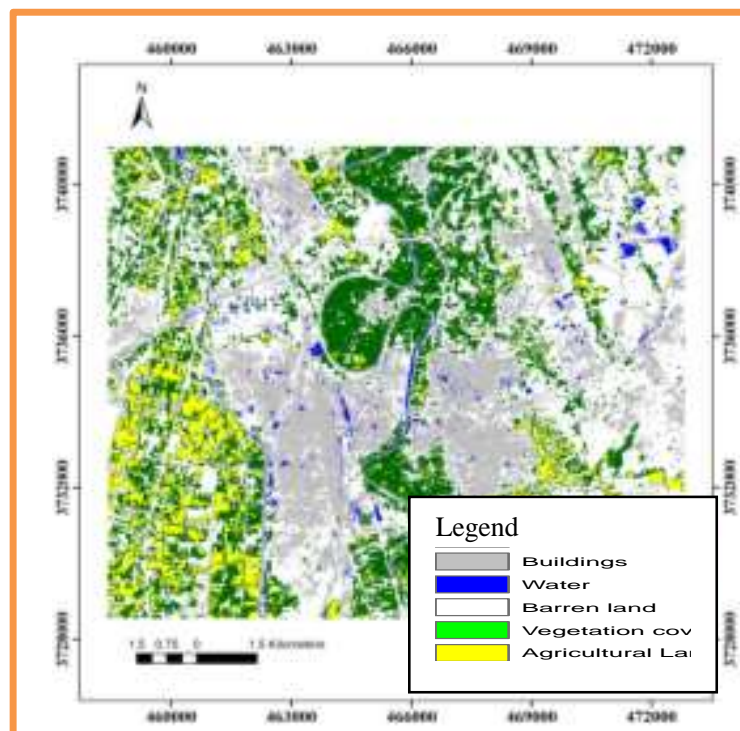

A

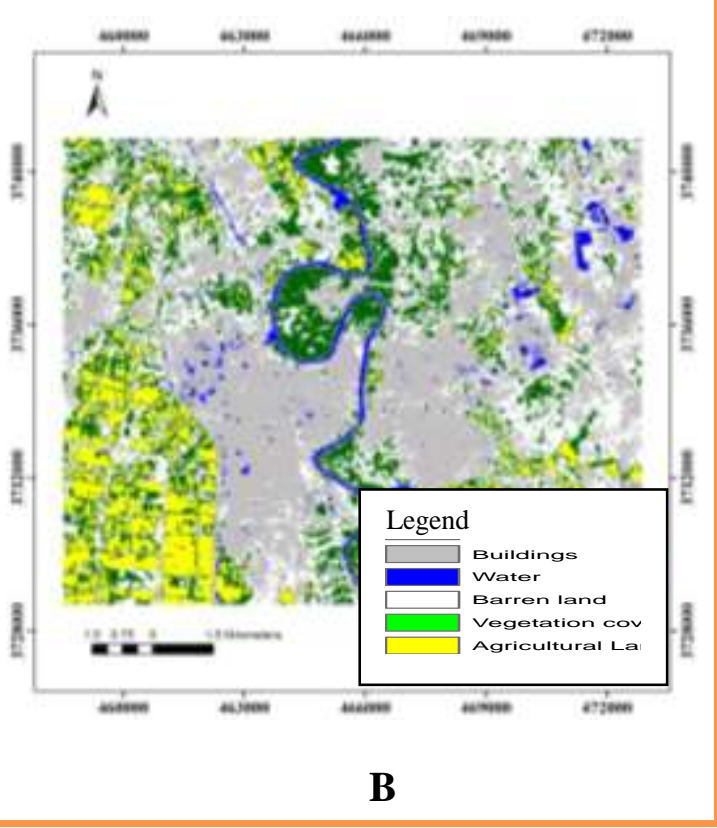

B

Figure 6.NDWI map of the study area and for the two periods 2014 (A) and 2019 (B).

Normalized Differences Built- up the Index(NDBI): This manual is used for urban or building-intensive urbanization (Marina and Bogdan, 2016), which represents the ratio 
between the spectral reflectance at the near infrared (NIR) $(0.76-0.90)$ and the medium infrared wavelength (MIR) (1.55-1.75) $\mu \mathrm{m}$, and its equivalent is $(19,23)$ :

$\mathrm{NDBI}=(\mathrm{MIR}-\mathrm{NIR}) /(\mathrm{MIR}+\mathrm{NIR}) \ldots . .3$
Using the Erdas Imagine V.14 program and the ArcMap 10.3.1 program, the NDBI map of the study area and for the periods 2014 and 2019 has been prepared and categorized as in Figs. 7 and 8.

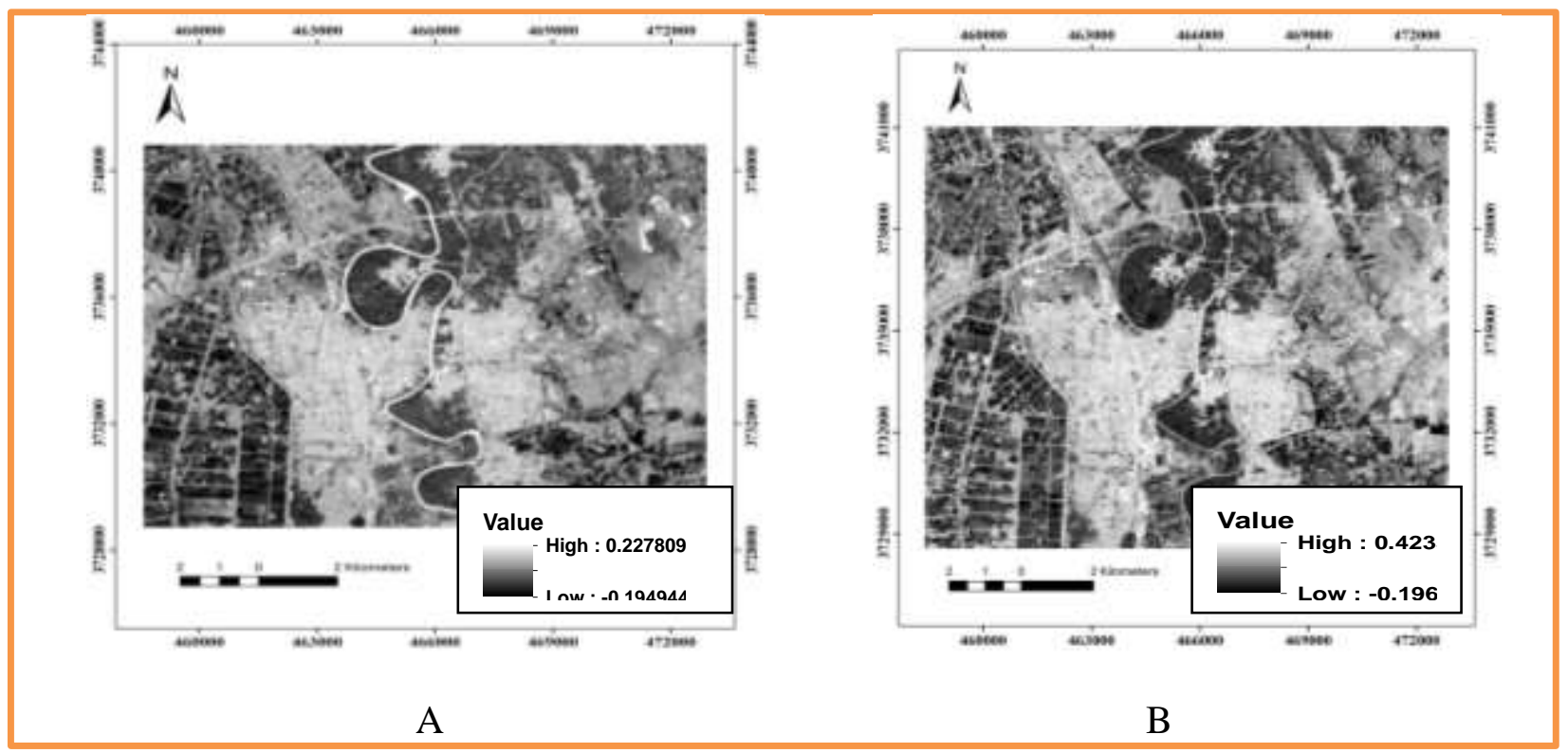

Figure 7. NDBI map of the study area and for the two periods 2014 (A) and 2019 (B).
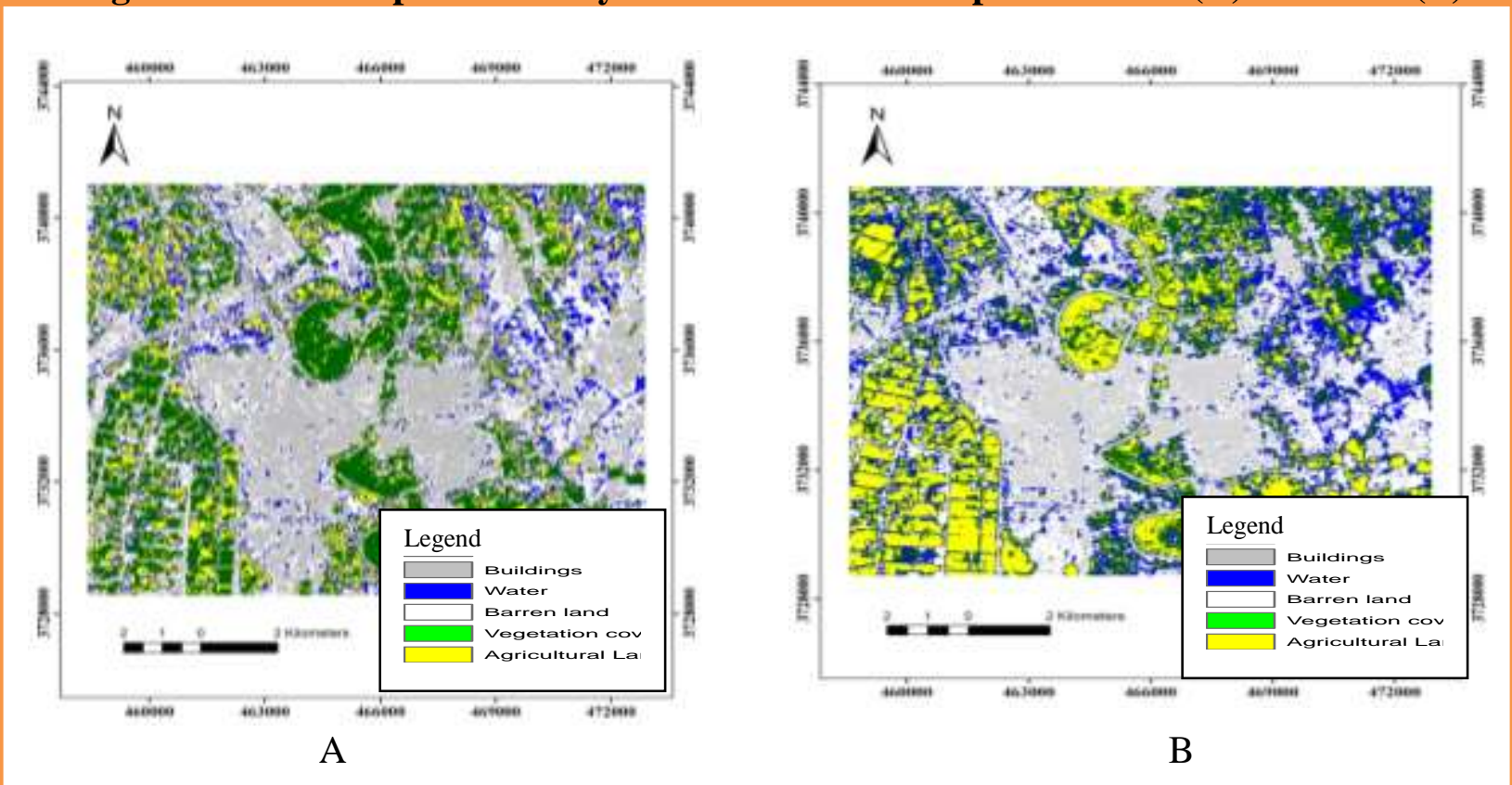

Figure 8. NDBI classified map of the study area and for the two periods 2014 (A) and 2019 (B)

RESULTS AND DISCUSSION

Normalized Difference Vegetation Index

(NDVI): The values of NDVI have a range ranging from $(+1$ to -1$)$. In general, the result if positive is an indication that the cell has a plant cover. The higher the resulting positive value, the greater the vegetative and density of the plant as show in Table 1 and Figure 9.
Normalized Differences Built- up the Index(NDBI): Development of the NDBI manual is based on the distinct spectral response of the built-up areas that have high reflectivity at the intermediate infrared wavelength and reflectivity Less at wavelengths Near Infrared. Therefore, when NDBI applies to satellite Image, urban or built-up areas appear to be bright white and 
positive digital values, while other areas appear dark with negative or zero numerical values .

Normalized Differences Water Index (NDWI)

Table 1. Statistical values of NDVI, NDWI, NDBI indices used in the study

\begin{tabular}{|ccccccccc|}
\hline \multirow{2}{*}{$\begin{array}{c}\text { The } \\
\text { Index }\end{array}$} & \multicolumn{2}{c}{ Maximum } & \multicolumn{2}{c}{ Minimum } & \multicolumn{2}{c|}{ Mean } & \multicolumn{2}{c|}{ Stan. Deviation } \\
\cline { 2 - 10 } & $\mathbf{2 0 1 4}$ & $\mathbf{2 0 1 9}$ & $\mathbf{2 0 1 4}$ & $\mathbf{2 0 1 9}$ & $\mathbf{2 0 1 4}$ & $\mathbf{2 0 1 9}$ & $\mathbf{2 0 1 4}$ & $\mathbf{2 0 1 9}$ \\
\hline NDVI & $\mathbf{0 . 5 7 2 9}$ & $\mathbf{0 . 5 6 8 2}$ & $\mathbf{- 0 . 2 4 3 3}$ & $\mathbf{- 0 . 2 1 9 0}$ & $\mathbf{0 . 1 6 4 7}$ & $\mathbf{0 . 1 7 4 5}$ & $\mathbf{0 . 2 3 7 0}$ & $\mathbf{0 . 2 2 8 6}$ \\
NDWI & $\mathbf{0 . 4 0 3 2}$ & $\mathbf{0 . 4 1 4 3}$ & $\mathbf{- 0 . 3 4 1 3}$ & $\mathbf{- 0 . 3 6 2 9}$ & $\mathbf{0 . 0 3 0 9 3}$ & $\mathbf{- 0 . 3 4 1 3}$ & $\mathbf{0 . 2 1 6 2}$ & $\mathbf{0 . 2 2 5 7}$ \\
NDBI & $\mathbf{0 . 2 2 6 1}$ & $\mathbf{0 . 4 2 1 1}$ & $\mathbf{- 0 . 1 9 4 9}$ & $\mathbf{- 0 . 1 9 6 6}$ & $\mathbf{0 . 0 1 5 6}$ & $\mathbf{0 . 1 1 2 2}$ & $\mathbf{0 . 1 2 2 2}$ & $\mathbf{0 . 1 7 9 3}$ \\
\hline
\end{tabular}

Tables 2,3 and 4 were prepared in areas for the study and for the periods 2014 and occupied by land items through the 2019.

classification maps of the spectral indices used

Table 2. Number of Pixels for the Land coverings of the study area in Baquba for each category and area and according to the categorized NDVI map.

\begin{tabular}{|c|c|c|c|c|c|c|c|}
\hline \multirow[t]{2}{*}{ No } & \multirow[t]{2}{*}{ Category } & \multicolumn{2}{|c|}{2014} & \multicolumn{2}{|c|}{2019} & \multirow{2}{*}{$\begin{array}{c}\text { Amount } \\
\text { of change } \\
/ \mathrm{km}^{2}\end{array}$} & \multirow{2}{*}{$\begin{array}{c}\text { Percentag } \\
\text { e change } \\
\%\end{array}$} \\
\hline & & $\begin{array}{l}\text { Number } \\
\text { of Pixels }\end{array}$ & $\begin{array}{l}\text { Area } \\
\mathbf{k m}^{2}\end{array}$ & $\begin{array}{c}\text { Number of } \\
\text { Pixels }\end{array}$ & $\begin{array}{l}\text { Area } \\
\mathbf{k m}^{2}\end{array}$ & & \\
\hline 1 & Building & 179128 & 40.304 & 199035 & 44.783 & 4.479 & 11.11 \\
\hline 2 & water & 188906 & 42.504 & 168360 & 37.881 & -4.623 & 10.88 \\
\hline 3 & Barren land & 155384 & 34.961 & 139608 & 31.412 & -3.550 & 10.15 \\
\hline 4 & $\begin{array}{l}\text { Vegetation } \\
\text { cover }\end{array}$ & 173088 & 38.945 & 164103 & 36.923 & -2.022 & 2.19 \\
\hline \multirow[t]{2}{*}{5} & $\begin{array}{c}\text { Agricultural } \\
\text { Land }\end{array}$ & 107204 & 24.121 & 132606 & 29.836 & 5.715 & 23.69 \\
\hline & Total & 803712 & 180.835 & 803712 & 180.835 & 0.000 & \\
\hline
\end{tabular}

When comparing Table 1 with Table 2, it is orchards, we deduce from this usefulness of reval a decrease in the area of vegetation 2.022 the NDVI guide in controlling the change in $\mathrm{km}^{2}(2.19 \%)$. This corresponds to the higher vegetation over other species and this is value of NDVI to 2014 of 0.5729 . This value consistent with the findings of many decreased in 2019 to 0.5682 . The higher researchers $(9,15)$. values of this index reflect vegetation, Or

Table 3. Number of Pixels for the Land coverings of the study area in Baquba for each category and area and according to the categorized NDWI map

\begin{tabular}{|c|c|c|c|c|c|c|c|}
\hline \multirow[t]{2}{*}{ No } & \multirow[t]{2}{*}{ Category } & \multicolumn{2}{|c|}{2014} & \multicolumn{2}{|c|}{2019} & \multirow{2}{*}{$\begin{array}{c}\text { Amount of } \\
\text { change / } \\
\mathrm{km}^{2}\end{array}$} & \multirow{2}{*}{$\begin{array}{c}\text { Percentag } \\
\text { e change } \\
\%\end{array}$} \\
\hline & & $\begin{array}{l}\text { Number } \\
\text { of Pixels }\end{array}$ & $\begin{array}{l}\text { Area } \\
\text { km }\end{array}$ & $\begin{array}{l}\text { Number } \\
\text { of Pixels }\end{array}$ & $\begin{array}{l}\text { Area } \\
\mathrm{km}^{2}\end{array}$ & & \\
\hline 1 & Building & 163244 & 36.730 & 187907 & 42.279 & 5.549 & 15.11 \\
\hline 2 & water & 123841 & 27.864 & 136209 & 30.647 & 2.783 & 9.98 \\
\hline 3 & Barren land & 201879 & 45.423 & 177896 & 40.027 & -5.396 & 11.87 \\
\hline 4 & $\begin{array}{l}\text { Vegetation } \\
\text { cover }\end{array}$ & 176929 & 39.809 & 156743 & 35.267 & -4.542 & 11.41 \\
\hline 5 & $\begin{array}{c}\text { Agricultural } \\
\text { Land }\end{array}$ & 137817 & 31.009 & 144958 & 32.615 & 1.606 & 5.18 \\
\hline & Total & 803712 & 180.835 & 803712 & 180.835 & 0.000 & \\
\hline
\end{tabular}

Since the highest values of NDWI refer to (27.864) by $2.783 \mathrm{~km} 2$. This indicates the water, Table 1 shows that the value of this guide in 2019 exceeds 0.4143 in 2014 (0.4032). When the water area is observed in $2019(30.647 \mathrm{~km} 2)$, it is larger than 2014 importance of the NDWI in monitoring intermittent water change, as we found in our study, which is consistent with many researchers $(2,25)$. 
Table 4. Number of Pixels for the Land coverings of the study area in Baquba for each category and area and according to the categorized NDBI map

\begin{tabular}{|lccccccc|}
\hline $\mathbf{N}$ & Category & \multicolumn{2}{c}{$\mathbf{2 0 1 4}$} & \multicolumn{2}{c}{2019} & $\begin{array}{c}\text { Amount of } \\
\text { change/ } \\
\mathbf{k m}^{2}\end{array}$ & $\begin{array}{c}\text { Percentage } \\
\text { change\% }\end{array}$ \\
& & $\begin{array}{c}\text { Number } \\
\text { of Pixels }\end{array}$ & $\begin{array}{c}\text { Area } \\
\mathbf{k m}^{2}\end{array}$ & $\begin{array}{c}\text { Number } \\
\text { of Pixels }\end{array}$ & $\begin{array}{c}\text { Area } \\
\mathbf{k m}^{2}\end{array}$ & & \\
\hline $\mathbf{1}$ & Building & $\mathbf{1 5 6 7 1 8}$ & $\mathbf{3 5 . 2 6 2}$ & $\mathbf{1 7 0 2 1 9}$ & $\mathbf{3 8 . 2 9 9}$ & $\mathbf{3 . 0 1 3}$ & $\mathbf{3 . 0 3 7}$ \\
$\mathbf{2}$ & water & $\mathbf{1 4 0 1 9 2}$ & $\mathbf{3 1 . 5 4 3}$ & $\mathbf{1 4 5 2 9 1}$ & $\mathbf{3 2 . 6 9 0}$ & $\mathbf{1 . 1 4 7}$ & $\mathbf{3 . 6 3}$ \\
$\mathbf{3}$ & Barren land & $\mathbf{1 7 9 0 7 0}$ & $\mathbf{4 0 . 2 9 1}$ & $\mathbf{1 8 4 1 9 6}$ & $\mathbf{4 1 . 4 4 4}$ & $\mathbf{1 . 1 5 3}$ & $\mathbf{2 . 8 6}$ \\
$\mathbf{4}$ & Vegetation cover & $\mathbf{1 8 0 4 5 8}$ & $\mathbf{4 0 . 6 0 3}$ & $\mathbf{1 5 0 0 0 8}$ & $\mathbf{3 3 . 7 5 2}$ & $\mathbf{- 6 . 8 5 1}$ & $\mathbf{1 6 . 8 7}$ \\
$\mathbf{5}$ & Agricultural Land & $\mathbf{1 4 7 2 7 3}$ & $\mathbf{3 3 . 1 3 6}$ & $\mathbf{1 5 3 9 9 6}$ & $\mathbf{3 4 . 6 4 9}$ & $\mathbf{1 . 5 1 3}$ & $\mathbf{4 . 5 6}$ \\
& Total & $\mathbf{8 0 3 7 1 2}$ & $\mathbf{1 8 0 . 8 3 5}$ & $\mathbf{8 0 3 7 1 2}$ & $\mathbf{1 8 0 . 8 3 5}$ & $\mathbf{0 . 0 0 0}$ & \\
\hline
\end{tabular}

Table 1 and 4, shows an increases in the value by the earth cover for the study area more and area of buildings respectively between 2014 and 2019. The importance of the NDBI indices in the study of change in Land coverings is indicated by many researchers $(10,19)$. Using Excel we were able to represent the values of the indices used in the study in the form of diagrams as reveal in Figure 9. In order to know the areas occupied accurately and compare them with the maps of the spectral indices used in the study we conducted the supervised classification of the Landsat 8 satellites for the 2014 and 2019 periods and using the Erdas Imagine program. The areas of the land varieties resulting from the classification were then calculated and as in Table 5.
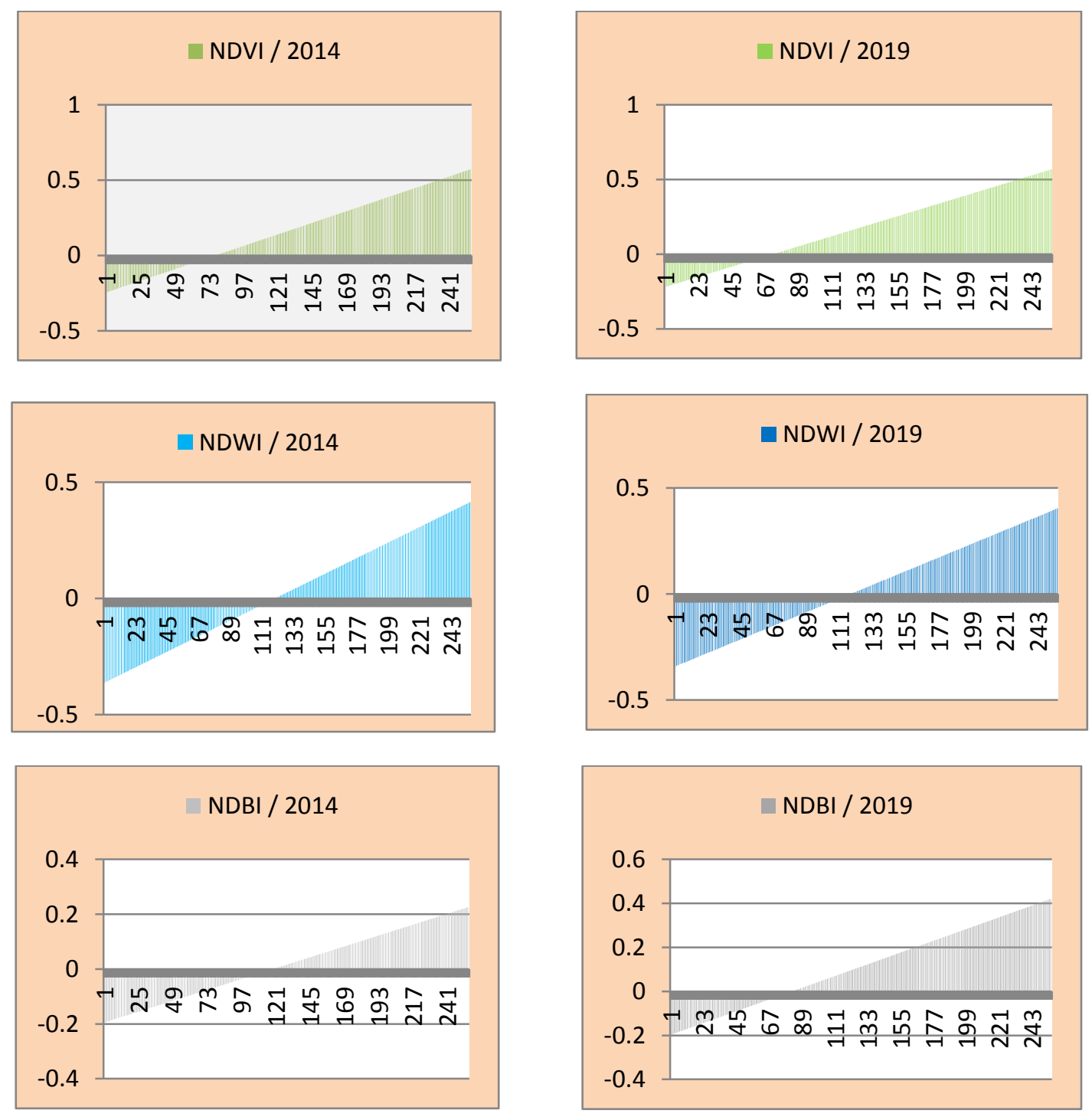

Figure 9. Diagrams of the indices used in the study and for the periods 2014 and 2019. 


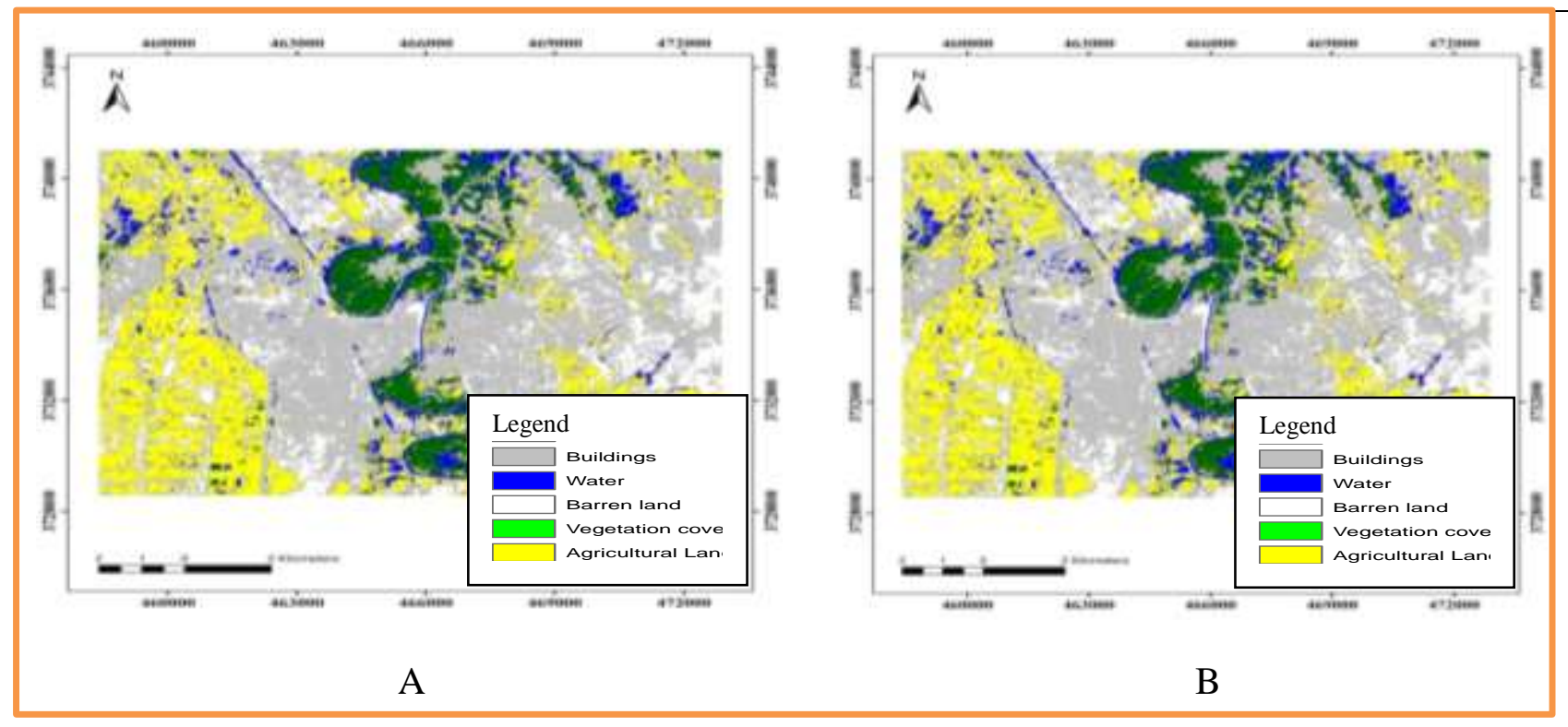

Figure 10. satellites images classified in the study area 2014 (A) and 2019 (B)

Table 5. Number of Pixels for the Land coverings of the study area in Baquba for each category and area and according to the classification map prepared by the satellites images

\begin{tabular}{|c|c|c|c|c|c|c|c|}
\hline \multirow[t]{2}{*}{ No } & \multirow[t]{2}{*}{ Category } & \multicolumn{2}{|c|}{2014} & \multicolumn{2}{|c|}{2019} & \multirow{2}{*}{$\begin{array}{c}\text { Amount } \\
\text { of } \\
\text { change / } \\
\mathbf{k m}^{2}\end{array}$} & \multirow{2}{*}{$\begin{array}{l}\text { Percentage } \\
\text { change\% }\end{array}$} \\
\hline & & $\begin{array}{l}\text { Number } \\
\text { of Pixels }\end{array}$ & $\begin{array}{l}\text { Area } \\
\mathbf{k m}^{2}\end{array}$ & $\begin{array}{l}\text { Number } \\
\text { of Pixels }\end{array}$ & $\begin{array}{l}\text { Area } \\
\mathbf{k m}^{2}\end{array}$ & & \\
\hline 1 & Building & 157784 & 35.501 & 169071 & 38.041 & 2.540 & 7.15 \\
\hline 2 & water & 122995 & 27.674 & 135112 & 30.400 & 2.726 & 9.95 \\
\hline 3 & Barren land & 212391 & 47.788 & 200121 & 45.027 & -2.761 & 5.77 \\
\hline 4 & $\begin{array}{l}\text { Vegetation } \\
\text { cover }\end{array}$ & 173213 & 38.975 & 160381 & 36.086 & -2.889 & 7.41 \\
\hline 5 & $\begin{array}{l}\text { Agricultural } \\
\text { Land } \\
\text { Total }\end{array}$ & $\begin{array}{l}137319 \\
803702\end{array}$ & 30.897 & $\begin{array}{l}139027 \\
803712\end{array}$ & $\begin{array}{r}31.281 \\
180.835\end{array}$ & $\begin{array}{l}0.384 \\
0.000\end{array}$ & 1.24 \\
\hline
\end{tabular}

The results in Table 5 shows a deterioration of the vegetation cover by $2,889 \mathrm{~km}^{2}$ and $7.41 \%$, followed by an increase in the area of buildings, water and agricultural lands by $2.540 \mathrm{~km}^{2}, \quad 2.726 \mathrm{~km}^{2}$ and $0.384 \mathrm{~km}^{2}$ respectively, As for the barren land, the percentage of decline was $5.77 \%$ and an area of $2.761 \mathrm{~km}^{2}$. When comparing the classification with the classification maps of the indices used in the study, the decrease in the area of the vegetation cover, according to the classification of NDVI classified by 2.022 $\mathrm{km}^{2}$ is an approach to the result of the supervised classification $(2,889 \mathrm{~km} 2)$, and there is an increase in the water area and according to the NDWI classification by (2.783) An approach to the area obtained from the vector classification $\left(2.726 \mathrm{~km}^{2}\right)$. The NDBI map showed a decrease in the area of buildings in both cases (11).

\section{Rating accuracy}

The process of assessing the accuracy of the classification of the elements of the different satellite image particularly important in the classification of vegetation covers and land classification. Through this accuracy, we can determine the compatibility of the classification with these covers, and the possibility of relying on the map prepared and used in the future. Therefore, the stratified random sampling method was used to evaluate the classification accuracy of the vegetation cover in Baquba by taking 75 ground control points to determine this accuracy. Using Kappa to measure precision, this measure measures the degree of difference between the land-based control points taken and the changes that have been identified in the classification map of the same site and compared them (13). This is a comparative 
measure. Many researchers have pointed out that the value of Kappa, which is greater than $80 \%$, is a good and appropriate classification and is recommended, whereas this value is limited to $40-80 \%$ and a medium rating of the image is shown. $40 \%$ show that this classification is poor and unreliable. The classification of 2019 was higher than the 2009 classification and was respectively $(0.89$,
0.88) as the overall average of the classification and this is considered good as shown in Table (6). Through this scale Kappa showed that there was a higher classification of (water, vegetation and agricultural land) for 2019 while the rest of the varieties were well classified. While the value of this measure for 2014 was also high for good by supervised classification.

Table 6. The Kappa statistical value for the classified images 2014 and 2019

\begin{tabular}{|c|c|c|c|}
\hline No & Category & $\begin{array}{l}\text { The value of } \\
\text { kappa } 2014\end{array}$ & $\begin{array}{c}\text { The value of kappa } \\
2019\end{array}$ \\
\hline 1 & Building & 0.85 & 0.86 \\
\hline 2 & water & 0.88 & 0.90 \\
\hline 3 & Barren land & 0.89 & 0.85 \\
\hline 4 & Vegetation cover & 0.90 & 0.91 \\
\hline \multirow[t]{2}{*}{5} & $\begin{array}{c}\text { Agricultural } \\
\text { Land }\end{array}$ & 0.91 & 0.93 \\
\hline & Accuracy \% & 0.88 & 0.89 \\
\hline
\end{tabular}

\section{REFERENCES}

1. Ahmed M., and F. Ahmed. 2016. Study vegetation cover densty and urbanization of agriculture land by using the techniques of remote sensing and geographic information systems in Saqlawia city. Iraqi .J.Desert.Stud $.6(1): 69-81$

2. Abhijit S., S. Panhalkar, and S. Bansode .2019..Impact of land use land cover change on land surface temperature using geoinformatics tachniques. International Journal of Research and Analytical Reviews (IJRAR).5(4):550-559

3. Branka C., and L. Barazzetti .2018. Damages from extreme flooding events to cultural heritage and landscapes: water component estimation for Centa River (Albenga, Italy). Adv. Geosci. 45: 389-395

4. Daniela E., Reza B., Ricardo D., and M. Datcu .2017. Land-cover change detection using local feature descriptore extracted from spectral indices..IEEE.IGARSS. 2017:19381941

5. Ebtihal H. 2014. Using (NDVI), (NDBI) and (NDWI) Indexes for change detection in land cover for selected area from the Province of Najaf for the period from (2001-2006) by using remote sensing data. Journal of KufaPhysics. 6(2) (in Arabic)pp:12-18

6. Jinru X., and S. Baofeng .2017. Significant remote sensing vegetation indices :A review of developments and applications. review article. Journal of Sensors. 1:1-17
7. Khalaf A. B. 2018. Estimation of the NDVI vegetation index to the Canaan forest using temporal spatial images. Journal of Biodiversity and Environmental Sciences. 12(6):204-209.

8. Kusay A., and M. Muntaha .2015. Assessment of land degradation of some biophysical parameters and soil properties by using remote sensing and GIS technologies. Iraqi Journal of Soil Science. 15(1):194-209

9. Mousa A., and A. Walid .2013. Using normalized difference vegetation index (NDVI) to assessment the changes of vegetations cover In surrounding area of Himreen Lake. Iraqi Journal of Science. 54(4):895-901

10. Marina R., and B. Bogdan .2016. Mapping land cover using remote sensing data and GIS techniques: A case study of prahova subcarpathians. Procedia Environmental Sciences .32:244-255

11. Manikandan S. 2018. Assessment of surface water dynamic using multiple water indices around Adama Woreda, Ethiopia.. ISPRS Annals of the Photogrammetry. Remote Sensing and Spatial Information Sciences. 6(5):181-188

12. Muhaimeed A. S., A. Ibrahim, and R. K. Abdulateef.2017. Using of remote sensing for monitoring geomorphological teompral changes for tigris river in Baghdad city. The Iraqi Journal of Agricultural Sciences. 48(1) (in Arabic): 512-551 
13. Lillesand T., W Ralph., and K. J. Chipmanand .2015. Remote Sensing and Image Interpretation, $7^{\text {th }}$ edition. University of California. USA.575-581

14.Lukasova V., Lang M., and J. Skvarenina .2014. Seasonal changes in NDVI in relation to phenological phases, LAI and PAI of beech forests, Baltic Forestry. 20(2): 248-262

15. Ozyavuz M., Bilgili C., and A. Salici .2015.Determination of vegetation changes with NDVI method. Journal of Environmental Protection and Ecology. 16(1):264-273

16. Ravi P., Singh S., and S. Mukherjee .2016. Normalized difference vegetation index (NDVI) based classification to assess the Change in land use/land cover (LULC) in lower assam, India. International Journal of Advanced Remote Sensing and GIS. 15(10): 1963-1970

17. Ranjeet K., Manmohan S., Shailendra K., Debjeet P., Nimisha T., and R Shekhar.2018. Land use/land cover change detection analysis using remote sensing and GIS of Dhanbad district, India. Eurasian Journal of Forest Science. 6(2): 1-12

18. Ravindra N., Kshama A., and N. Rajan .2018. Vegetation change detection in Delhi using normalized difference vegetation index (NDVI). International Journal of Information and Communication Technology .1(1): 2581 5873

19. Sushil T. 2017. Expploring the impact of Urban Growth on Land Suurface Temperature of Kathmandu Valley, Nepal. M.Sc. Thesis. Universitat Jaume I, Castellón, Spain .40-41

20. Ssentongo A., and D. Mutyaba .2018. Detecting forest cover and ecosystem service change using integrated approach of remotely sensed derived indices in the Central Districts of Uganda. South African Journal of Geomatics. 7(1):46-63
21. Shanmugapriya P., Rathika S., Ramesh T., and P. Janaki .2019. Applications of remote rensing in agriculture - A Review. Int.J.Curr.Microbiol.App.Sci. 8(1): 2270-2283 22. Thomas P., and S. Elias .2014. Assessing land degradation and desertification using vegetation index data: current frameworks and future directions. Remote Sens. 6: 9552-9575

23. Tanmoy B., and K. Sujit .2017. The analysis of land use land cover changes using geoinformatics and its relation to changing population scenariosin barasat municipality in north twenty four Parganas, West Bengal. International Journal of Humanities and Social Science Invention. 6(8):1-13

24. Taghreed A. H. .2018. Study of vegetation cover distribution using DVI, PVI, WDVI indices with 2D-space plot. IOP Conf. Series: Journal of Physics: Conf. Series. 1003 (2018) 012083

25. Vanessa S., S. Gabriela, I. Marília, and E. Alba .2019. Methodological evaluation of vegetation indexes in land use and land cover (LULC) classification. Geology, Ecology, and Landscapes : 1-12

26. Wheib K.2012. Spectral reflectance properties of soil surface and land covers of Al.SALMAN depression in southern Iraq. The Iraqi Journal of Agricultural Sciences. 43(4) $: 129-140$

27. Zahraa R., and S. Ahmad. 2016. The study of temporal changes on land cover/ land use prevailing in Baghdad governorate using RS $\&$ GIS. The Iraqi Journal of Agricultural Sciences. 47(3): 846-855. 